\title{
A systematic literature review of crowdfunding and sustainability: highlighting what really matters
}

\author{
Alexa Böckel ${ }^{1}$. Jacob Hörisch ${ }^{1}$ D $\cdot$ Isabell Tenner ${ }^{1}$ \\ Received: 8 November 2019 / Accepted: 21 May 2020 / Published online: 8 June 2020 \\ (c) The Author(s) 2020
}

\begin{abstract}
This article systematically reviews literature at the intersection of crowdfunding and sustainability. It analyzes the extent to which the current research foci in crowdfunding and sustainability contribute to unleashing the potential of crowdfunding for sustainable development. The findings highlight that the research field has a relatively short history but already shows signs of growing maturity. With regard to the research foci, the results reveal misbalances between the relevance ascribed to various aspects in research and in practice. For example, the research primarily deals with the types of crowdfunding that make up the smallest shares of the crowdfunding volume. Likewise, a research gap related to the post-funding phase as well as to environmental oriented projects is identified. On this basis, it is recommended to focus future research on the impact of crowdfunding projects on staying within the planetary boundaries and on crowdfunding projects dealing with environmental issues or integrating the social and environmental dimension of sustainability. Additionally, the potential of crowdfunding as a legitimizing function for sustainable ventures needs to be researched.
\end{abstract}

Keywords Crowdfunding $\cdot$ Sustainability $\cdot$ Systematic literature review $\cdot$ Sustainable development $\cdot$ Sustainable entrepreneurship

JEL Classification G24 · G29 · Q56 - Q59

Electronic supplementary material The online version of this article (https://doi.org/10.1007/s1130 1-020-00189-3) contains supplementary material, which is available to authorized users.

Jacob Hörisch

hoerisch@leuphana.de

1 Centre for Sustainability Management, Leuphana University of Lüneburg, Lüneburg, Germany 


\section{Introduction}

There is increasing agreement about the high relevance of addressing urgent environmental and social problems, such as climate change, biodiversity loss, and global injustice (e.g., Rockström et al. 2009; Tan 2014; Dempsey 2015). Sustainable entrepreneurs aim at addressing such challenges by introducing innovative products, services, or processes that benefit the environment and communities (Shepherd and Patzelt 2011). However, due to the higher associated risk of these ventures, such entrepreneurs often face difficulty in financing their activities (e.g., Calic and Mosakowski 2016; Lehner 2013; Ridley-Duff 2009). As a relatively new financing mechanism, crowdfunding is increasingly expected to be able to close this funding gap and, thus, to contribute to sustainable development (e.g., Hörisch 2015; Jovanovic 2018). Crowdfunding is most commonly defined as "the efforts by entrepreneurial individuals and groups - cultural, social, and for-profit - to fund their ventures by drawing on relatively small contributions from a relatively large number of individuals using the internet, without standard financial intermediaries" (Mollick 2014, p. 2). Hence, using crowdfunding can be perceived as an entrepreneurial act in itself (Mollick 2014). Generally, the empirical importance of crowdfunding in financing new ventures (whether sustainability-oriented or conventional) is growing rapidly, and crowdfunding is expected to reach a global volume of USD 90 billion in 2020 (Messeni Petruzzelli et al. 2019).

Acknowledging the growing relevance of crowdfunding, crowdfunding research has recently been synthesized in systematic literature reviews. Jovanovic (2018) drew on 90 scientific papers to identify research gaps and, in doing so, revealed that eight percent of all research on crowdfunding is related to sustainability, thus highlighting the importance of this intersection but not analyzing it in depth. Another systematic literature review, by Bouncken et al. (2015), provided a general overview of the crowdfunding literature published between 2000 and 2014 by explaining the basic concepts and common understandings of crowdfunding. Further, systematic literature reviews have been conducted on specific aspects or types of crowdfunding, such as on decision-making processes (Hoegen et al. 2018), financial motivations in reward- and donation-based crowdfunding (Alegre and Moleskis 2019), and the benefits of crowdfunding (De Luca et al. 2019). However, in the existing literature reviews on crowdfunding, no references have been made to financing sustainability-oriented projects, although Messeni Petruzzelli et al. (2019), in their conceptual paper, did analyze crowdfunding specifically to draw implications for sustainable entrepreneurship.

Similar to the field of crowdfunding, previous research has also systematically reviewed literature on social entrepreneurship (Lehner and Kansikas 2013; Kraus et al. 2014), sustainable entrepreneurship (Johnson and Schaltegger 2019), and, more specifically, ecological sustainability entrepreneurship (Gast et al. 2017). These works revealed that the potential of sustainable entrepreneurship is increasingly reflected by a growing body of relevant academic literature. Furthermore, the systematic literature reviews helped to overcome the pre-paradigmatic status of the research field (Lehner and Kansikas 2013). However, they also highlighted that a 
lack of financing is a key obstacle that keeps the potential of sustainable entrepreneurship from being unleashed.

Crowdfunding is expected by many to remove this obstacle. Consequently, studies on the link between crowdfunding and sustainability are gaining ground in the academic literature. In line with the great expectations that crowdfunding is confronted with in the context of sustainability, two motivations arise for conducting a systematic literature review in this research field: on the one hand, the interface between the research fields of crowdfunding and sustainable entrepreneurship has not yet been systematically mapped, and researchers as well as practitioners face the challenge of making use of the insight gained by prior research. On the other hand, the importance of efficiently and effectively making use of crowdfunding for sustainable development is becoming increasingly apparent. Many sustainability problems are becoming even more pressing (e.g., Steffen et al. 2015), and successfully addressing these problems will require vast financial means (e.g., Casado and de Molina 2009; Barosh et al. 2014; Tseng and Hung 2014; Akerboom et al. 2020). As such, this study addresses the following research question by systematically analyzing the extant literature on crowdfunding and sustainability.

To what extent do the research foci in the scientific literature on crowdfunding and sustainability contribute to unleashing the potential of crowdfunding to facilitate sustainable development?

Based on the understanding of systematic literature reviews brought forward by Tranfield et al. (2003, p. 208), this article serves "to map and to assess the existing intellectual territory" of crowdfunding in the realm of sustainability. As no systematic literature review of crowdfunding and sustainability currently exists, researchers and practitioners who aim to make use of the growing body of (potentially contradictory) knowledge face difficulties in gaining a comprehensive picture (cf. Tranfield et al. 2003). Likewise, academics in the field run the risk of overlooking existing patterns, re-inventing the wheel, or choosing inappropriate methods when conducting further research in the field (cf. Edmondson and McManus 2007). Consequently, this study aims to combine the research fields of sustainable entrepreneurship and crowdfunding in a systematic literature review, as these fields not been linked in such a review so far.

The remainder of this paper is structured according to prior systematic literature reviews and guidelines (e.g., Fisch and Block 2018; Buchheim et al. 2019; Heidingsfelder and Beckmann 2019). Section 2 summarizes the relevant literature and its concepts, which inform the structure of this review. The methodology of the systematic literature review is described in Sect. 3, while Sect. 4 presents the results of the analysis. Finally, the results are discussed in relation to prior research, and conclusions for academia and practice are drawn in Sect. 5. 


\section{Relevant concepts in the research field}

Crowdfunding offers a number of benefits for entrepreneurs. The most prominent function of crowdfunding is financing new ideas or existing ventures (Lehner 2013). Yet, crowdfunding can also serve marketing purposes (Hörisch 2018), as it may increase attention among potential customers, the general public, and the media (Burtch et al. 2014; Lambert and Schwienbacher 2010; Mollick 2014). Likewise, crowdfunding can be used as a market test that signals whether potential users are interested in the respective offering of a crowdfunding campaign (Belleflamme et al. 2014; Lam and Law 2016). Moreover, crowdfunding can fulfil a legitimizing function if the support by the crowd is used to signal public approval of the cause (Martin 2012; Lehner and Nicholls 2014; Vasileiadou et al. 2016).

In the academic literature, four different types of crowdfunding are differentiated. In donation-based crowdfunding, supporters receive no reward in return for their financial support. It is mostly non-profit and non-governmental organizations that make use of this original form of crowdfunding (Hörisch 2015; Lehner 2013). Supporters in reward-based crowdfunding receive material or immaterial returns on their investments, commonly in form of the product to be funded. As explained forward by Mollick (2014), reward-based crowdfunding is the most frequently used form of crowdfunding. Furthermore, two investment-based types of crowdfunding exist, in which monetary returns are disbursed among the investors. In equity-based crowdfunding (also called crowdinvesting), investors receive financial returns on their investment in the case that the venture is profitable (Mochkabadi and Volkmann 2018). Similar to investments in the stock market, this type of crowdfunding is associated with the highest risk for investors (Bapna 2019). Last, lending-based crowdfunding (also called debt-based crowdfunding or crowdlending) is comparable to a bank loan, as supporters act as lenders and receive a previously defined interest rate within a certain period of time (Bruton et al. 2015). Lending-based crowdfunding holds the largest share of the global funding volume derived from crowdfunding (Massolution 2015).

Two different funding phases in the crowdfunding process can be differentiated, which are similar for each of the aforementioned crowdfunding types. The scientific literature distinguishes between the pre-funding phase and the post-funding phase (e.g., see Jovanovic 2018; Hörisch 2019). The pre-funding phase describes the period lasting until the funding on the crowdfunding platform is completed; it includes the preparation of the campaign, communication and marketing among the target groups, and the actual funding period. In contrast, the post-funding phase begins after the crowdfunding campaign has finished. In this phase, the project initiators must communicate its successes or failures to supporters, distribute promised returns, and, above all, realize the project by implementing the advertised measures.

Various players are active in the crowdfunding process, which, from an academic perspective, also represent different potential research foci. Jovanovic (2018) and Messeni Petruzzelli et al. (2019) identified four important players: (1) the project creator, who launches the crowdfunding campaign and collects money for the purpose of realizing the specific cause or offering, (2) the campaign to be funded, 
representing its cause or offering, (3) the supporters (i.e., the crowd) backing the project with small sums of money, and (4) the crowdfunding platform, which acts as an internet-based intermediary between the project creator and its supporters.

Past crowdfunding studies have predominantly focused on factors influencing the success of crowdfunding campaigns in the pre-funding phase. In particular, Mollick (2014) revealed that the network of the project initiator is relevant, as is the signaled quality of the project to be funded. Further, it was found that early financial contributions to crowdfunding campaigns can lead to a higher chance of success (Colombo et al. 2015). With regard to sustainability, numerous studies have investigated the influence of the sustainability orientation of crowdfunding campaigns on their funding success in different contexts (e.g., Vismara 2019; Calic and Mosakowski 2016; Hörisch 2015). A sustainability orientation in equity crowdfunding can lead to more restricted investors (Vismara 2019) but not necessarily to increased funding success in equity- and reward-based crowdfunding (Vismara 2019; Hörisch 2015). In contrast, Calic and Mosakowski (2016) found that in reward-based crowdfunding, social-orientated campaigns lead to higher success rates, as do environmental-oriented campaigns that fund technology projects. In some contexts, project creativity is a mediating factor, while in others, third-party endorsements lead to greater resource acquisition (Calic and Mosakowski 2016). Another explanation for the positive impact of a sustainability orientation may be the community logic that restricted investors follow in equity-based crowdfunding: as restricted investors in crowdfunding only acquire a marginal share of the company, not only are they profit-driven but they also pursue community values and a cooperative capitalism approach (Vismara 2019).

Regarding the post-funding phase, less aspects have been analyzed so far. As an exception, Cumming et al. (2019) examined how ownership impacts post-offering outcomes, such as long-run success of the crowdfunded ventures. Another study on the long-run success of equity crowdfunding campaigns was conducted by Signori and Vismara (2018). The degree of involvement of investors is found to have a strong impact on long-run success in the post-funding phase (Signori and Vismara 2018). In the context of crowdfunding for sustainable projects, Hörisch (2019) revealed that only a minority of crowdfunding campaigns disclose information on their actual contribution to sustainable development in the postfunding phase.

According to Mollick (2014, p. 2), crowdfunding is considered an opportunity for "entrepreneurial financing" and thus can itself be regarded as an entrepreneurial act. It serves as a supplement to existing financing mechanisms, such as banks, credit institutes, and angel investors, and thus provides a novel way in which entrepreneurs can access financial assets. In particular, sustainable entrepreneurs, who often face difficulties in receiving funds, are expected to benefit from this new phenomenon (Lehner 2013; Calic and Mosakowski 2016; Hörisch 2018). As described by Shepherd and Patzelt (2011, p. 142), sustainable entrepreneurs focus "on the preservation of nature, life support, and community in the pursuit of perceived opportunities to bring into existence future products, processes, and services for gain, where gain is broadly construed to include economic and non-economic gains to individuals, the economy, and society." Thus, 
sustainable entrepreneurs follow the "triple bottom line" as they simultaneously focus on the economic, environmental, and social dimensions of sustainability (Thompson et al. 2011). While the environmental dimension is mostly concerned with the biosphere, the conservation of nature and the development of the natural landscape, the social dimension covers aspects such as living conditions of humans, cultures, traditions and well-being of different groups (Pawłowski 2008). Against this backdrop, sustainable entrepreneurship is a driving force toward sustainable development, as it contributes to the solution of environmental-, social-, or sustainability-related problems (Kardos 2012).

\section{Methodology}

The systematic literature review was conducted according to the guidelines brought forward by Tranfield et al. (2003) and adapted by Hansen and Schaltegger (2016). It comprised six steps, including (1) the identification of research, (2) the development of inclusion and exclusion criteria, (3) the selection of studies, (4) the assessment of study quality, (5) data extraction, and (6) data synthesis.

\subsection{Data collection process}

Within the scope of the first step of the data collection process - that is, the identification of research (1) Tranfield et al. (2003) — all relevant keywords were identified in order to cover the research field in its entirety. The keywords for the search string included two aspects, covering the sustainability orientation and the realm of crowdfunding. To capture the first aspect, the search terms "sustainab*", "eco*", "environment*", "social", "prosocial", "pro-social", or "ethic*" were used. In so doing, the economic dimension of sustainability was purposefully excluded from the search string, because economic reviews of crowdfunding have already been conducted (cf. Bouncken et al. 2015; Jovanovic 2018) and crowdfunding, by definition, contains an economic dimension (cf. Mollick 2014). This first aspect was combined with a second, relating to crowdfunding, which included the search terms "crowd invest*", "crowdinvest*", "crowd fund*", or "crowdfund*" (Table 1). Therefore, the second search string ensured that all possible crowdfunding types were captured, including donation-based crowdfunding, reward-based crowdfunding, lending-based, and equity-based crowdfunding. This search string led to 383 articles on Scopus that mentioned the search terms in their titles, abstracts, or keywords. Scopus was chosen as the search engine because it is the world's largest database of peer-reviewed literature. Additionally, it covers multiple disciplines, thus reflecting the interdisciplinary nature of the research field. Alternative databases, such as Web of Sciences, were not considered because applying the same search string in these databases led to the identification of fewer articles.

With regard to the development of inclusion and exclusion criteria (2), only journal articles written in English were included. Additionally, these articles were 


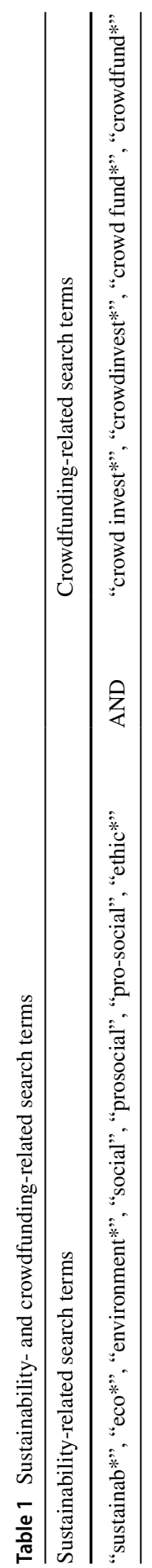


restricted to articles published by the end of the year 2018 (and articles in press, in cases where they had been accepted for publication by the end of the year 2018). The criteria for inclusion and exclusion were kept deliberately open to fully capture the emerging field (2). Nevertheless, the focus of the research had to be on sustainability-related topics or projects and crowdfunding within the same article.

The selection of studies (3) was conducted by three coders. All coders participated in a coding workshop. First, each abstract was separately coded by two researchers, who assessed whether the paper addressed crowdfunding (coded as 1 if so and 0 if not) and sustainability-related topics (coded as 1 if so and 0 if not). The percentage of agreement between the coders (96.8\% for crowdfunding and $85.7 \%$ for sustainability) reflected a high level of inter-coder reliability. If both coders disagreed, a third researcher coded the abstracts independently to decide upon the inclusion or exclusion of the respective articles. After all the abstracts were coded, 105 articles met the mentioned criteria and were read and analyzed. Of these, 22 had to be excluded after reading the entire article due to a missing focus on either sustainability or crowdfunding that was not observable based on the article's abstract. Hence, the final sample (see Appendix I in ESM) for this systematic literature review consisted of 83 papers (Fig. 1). Thus, the sample size was only slightly smaller than that of the literature review by Jovanovic (2018), which focused on crowdfunding in general $(n=90)$.

As all the included papers were published in peer-reviewed journals and the goal of this systematic literature review was to capture the entire field of research, no further assessment of the studies' quality was applied (4).

\subsection{Data analysis}

The first step in extracting data from the selected articles (5) was to design a coding scheme. MAXQDA was the software program used for the computer-assisted qualitative text analysis. Furthermore, to assess the emerging field of crowdfunding and sustainability and to synthesize the data (6), two steps were undertaken. First, general aspects were considered, such as geographic orientation, the applied theories and methodology used, and the maturity of the research field, which was evaluated using the concept of methodological fit outlined by Edmondson and McManus (2007) as a guideline. The concept suggests criteria for locating research fields on a continuum from a nascent to intermediate to mature state of theory and research. To construct these categories, methodological fit considers the type of research questions dealt with, the embeddedness in prior work, the methods used, and the state of theorizing in the field.

In this way, nascent theory research typically uses suggestive theories or suggests elements of theorizing for the specific research field. Furthermore, it is characterized by the use of qualitative methodologies. In contrast, mature theory research uses quantitative research methodologies. It typically relies on testing hypotheses that have been set up based on established theories, which can be confirmed or specified by the empirical work. Taking a middle position, intermediate theory research uses hybrid types of data collection, drawing on both qualitative and quantitative data. It 


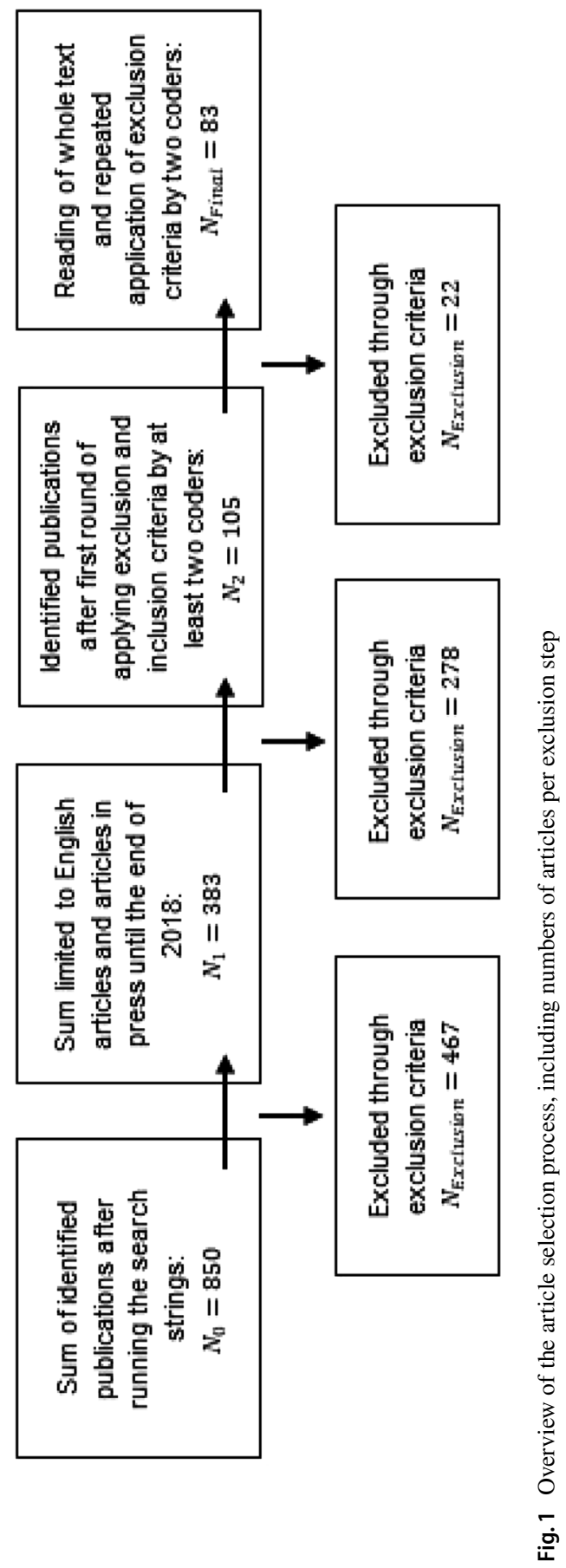


frequently attempts to build provisional theorizing in the field by, for example, integrating previously separate research fields (Edmondson and McManus 2007).

Applying the methodological fit concept allows researchers to design appropriate research projects in the field of interest, helping them to ask the right questions, choose the most powerful methods, and effectively build on prior work (cf. Edmondson and McManus 2007; Bouchard 1976).

Finally, synthesis (6) was conducted, in order to answer the above-formulated research question. For this purpose, an interpretative, thematic analysis was carried out to identify the research foci and potential contributions of crowdfunding to sustainable development. The coding scheme developed in step (5) was applied, and the analysis was informed by theories and concepts from the fields as mentioned in the second section: To gain an overview of what crowdfunding types are most frequently researched, the different crowdfunding types, as defined in Sect. 2.1, were one element of the coding scheme. Further, the focus of the examined articles in terms of the different crowdfunding phases was coded (i.e., pre-funding, post-funding, or no focus), as was the focus of the articles in terms of research objects (i.e., a focus on supporters, a crowdfunding campaign, a platform, a project creator, the phenomenon of crowdfunding in general, or other research objects).

Based on the debate about whether (and how) a sustainability orientation influences the success of crowdfunding campaigns, three different categories were established. The first category of analysis assessed whether success was examined at all in the research article. The second category covered whether an assumption concerning sustainability orientation was provided, while the third category determined whether the study found evidence of the positive or negative influence of a sustainability orientation on crowdfunding success.

\section{Results of the systematic review}

\subsection{Bibliographic results}

The temporal evolution of the research field unfolded as follows: The first article addressing the intersection between sustainability and crowdfunding was published in 2011; however, no further paper on sustainability and crowdfunding was published until 2013 (Fig. 2). Hence, the research field on crowdfunding and sustainability is still in its early phase, but the number of papers published per year is constantly increasing. With regard to the research methods used, before 2017, most of the studies were qualitative, while the use of mixed-method studies was increasing. Quantitative methods gained dominance only recently, in 2018; as such, there is still a dominance of qualitative and conceptual approaches, which is typical for nascent theory research (Edmondson and McManus 2007).

Regarding the application of theories, only a few signs of growing maturity could be found. Of the 83 articles analyzed, only 47 made use of theories. Remarkably, the theories employed were not specifically developed for the field of crowdfunding or sustainability (or their intersection) but were rather general theories from neighboring research disciplines. Among these, no dominant theoretical approach could be 


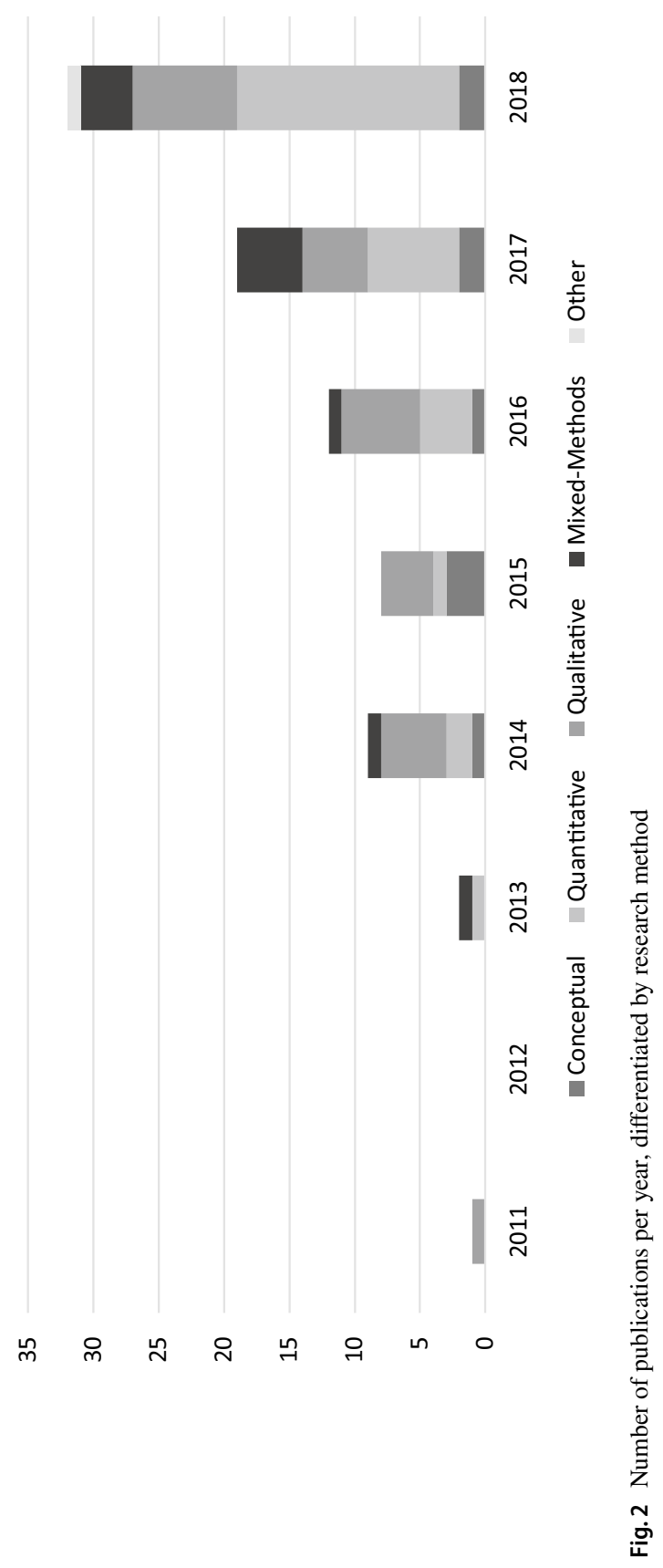


identified. With only five applications, the theory of warm-glow giving was the most frequently applied approach, followed by altruism and signaling theory (applied four times each).

Likewise, it was not possible to identify a leading journal in the field, as no journal was found to host more than four publications on sustainability and crowdfunding. Interestingly, while three journals published at least three relevant articles, two of these journals were rather broad, sustainability-oriented journals (Sustainability; Journal of Cleaner Production), whereas one (New Media \& Society) was more specialized. The analysis of the publication outlets also suggested that research in the field is only scarcely published in top-ranked management journals, as only five articles in the final sample were published in journals ranked in the top categories (i.e., $4 *$ or 4 ) according to the Chartered Association of Business Schools Academic Journal Guide 2018 (cf. Harzing 2019).

\subsection{Focus of the literature}

With regard to the question of which current research foci could be identified in the scientific literature on crowdfunding and sustainability, Fig. 3 provides an overview of the crowdfunding types examined in research in comparison to the practical relevance of the respective crowdfunding types by funding volume in 2015 (cf. Massolution 2015). Interestingly, donation-based crowdfunding received the highest level of attention in the research $(29 \%$ of all examined papers dealt with donation-based crowdfunding), while this crowdfunding type currently constitutes only $8 \%$ of the market volume of global crowdfunding (Massolution 2015). Similarly, reward-based crowdfunding seemed to be overrepresented in research (16\%), compared to its market share of $8 \%$. In contrast, lending-based crowdfunding is by far the most relevant type of crowdfunding in practice, if assessed by market volume (76\%), but it was only addressed in $16 \%$ of the publications. This imbalance was also reflected in the crowdfunding platforms examined. Overall, 55 of the 83 papers examined specific platforms. Among these, Kickstarter, a reward-based crowdfunding platform, was the most frequently chosen data source (16 publications). With regard to geographical distribution, a relatively even spread was found in the current literature on crowdfunding and sustainability, with $72 \%$ of all publications demonstrating a geographical focus. Of these, 38 publications focused on a single country, five publications compared two countries and 17 focused on more than two countries. Interestingly, the most frequently chosen geographic focus was on European countries (in ten publications), followed by a focus on the United States (US) (in six publications).

In terms of the research objects analyzed, $33 \%$ of the publications studied the phenomenon of crowdfunding in general, e.g. how crowdfunding can function as a financing mechanisms in different contexts (e.g. Elkuch et al. 2013; Zeng 2018). Another frequent research object was crowdfunding campaigns (25\%), such as in studies that focused on the success factors of campaign design or the type of campaigns conducted. Likewise, the supporters of crowdfunding (20\%) were frequently analyzed, such as in studies that reviewed their motivations or attitudes. In contrast, 

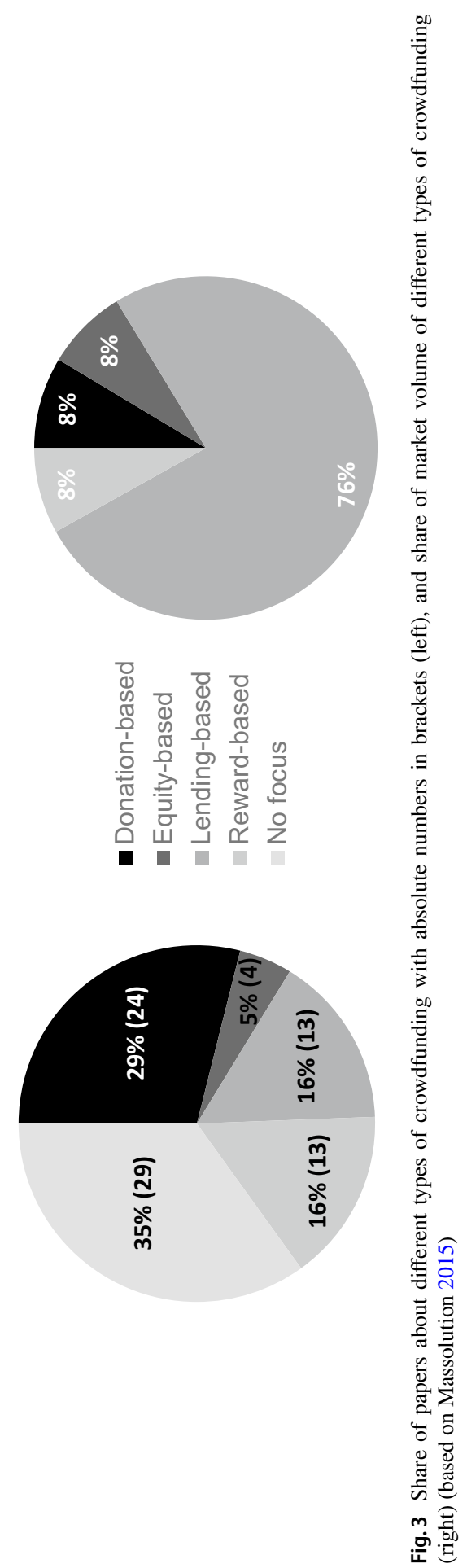

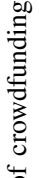

ڤ

艺

氖

4

$\stackrel{\Xi}{\Xi}$

彔

फ

త్

छ

$\stackrel{\hat{\vec{d}}}{\mathscr{E}}$ 
Table 2 Number of articles examining different research objects

Table 3 Number of articles examining different sustainability dimensions

Table 4 Number of articles assuming and examining the influence of a sustainability orientation on success

\begin{tabular}{lll}
\hline Research object & $\begin{array}{l}\text { Number of } \\
\text { articles }\end{array}$ & $\begin{array}{l}\text { Percentage of } \\
\text { articles (\%) }\end{array}$ \\
\hline Crowdfunding as a phenomenon & 27 & 33 \\
Campaign & 21 & 25 \\
Supporters/backers/funders & 17 & 20 \\
Others & 8 & 10 \\
Project creator/founder & 7 & 8 \\
Platform & 3 & 4 \\
\hline
\end{tabular}

\begin{tabular}{lll}
\hline Sustainability dimension & $\begin{array}{l}\text { Number of } \\
\text { articles }\end{array}$ & $\begin{array}{l}\text { Percentage } \\
\text { of articles } \\
(\%)\end{array}$ \\
\hline Social & 61 & 74 \\
Ecological & 11 & 13 \\
Social and ecological & 11 & 13 \\
\hline
\end{tabular}

\begin{tabular}{lcc}
\hline Assumption & $\begin{array}{l}\text { Number of } \\
\text { articles }\end{array}$ & $\begin{array}{l}\text { Percentage of } \\
\text { articles (\%) }\end{array}$ \\
\hline Positive & 20 & 24 \\
Negative & 0 & 0 \\
Result & 13 & 16 \\
Positive influence on success & 3 & 4 \\
No influence on success & 2 & 2 \\
Negative influence on success & & \\
\hline
\end{tabular}

the initiators of crowdfunding projects $(8 \%)$ and the different crowdfunding platforms available (4\%) have so far received only scant attention, despite their centrality to the crowdfunding process. The remaining $10 \%$ of publications chose other research objects or combined multiple research objects in their analyses, e.g. different crowdfunding types and different platforms and how they contribute to the financing of social ventures (Meyskens and Bird 2015). The absolute numbers as well as the relative shares relating to the examined papers' research objects are displayed in Table 2, below.

Regarding articles' focus on the different dimensions of sustainability, as shown in Table 3, a clear dominance of the social dimension can be observed, as 61 of the 83 publications focused on social aspects. In contrast, only eleven publications showed an emphasis on environmental aspects, with the remaining 11 papers combining the environmental with the social dimension of sustainability. 
If academia strives to contribute to unleashing the potential of crowdfunding for sustainable development, it is crucial to analyze how successful sustainabilityoriented crowdfunding projects are (Calic and Mosakowski 2016). Therefore, it is unsurprising that the success rate of crowdfunding initiatives was analyzed in $35 \%$ of the examined publications (i.e., 29 publications) on sustainability and crowdfunding. Among these, 23 publications focused on success in terms of the financing function of crowdfunding, while only one investigated success based on the number of supporters of a campaign, which is an indicator of marketing success. An additional five papers analyzed success in general (see Table 4).

Interestingly, 20 publications dealing with success assumed the positive influence of a sustainability orientation (or one of its sub-dimensions) on crowdfunding success, while no articles assumed a negative or neutral influence. The majority of the papers actually investigating this link between sustainability orientation and crowdfunding success largely confirmed this view; 13 papers revealed a positive influence, whereas only two found a negative influence of sustainability orientation on crowdfunding success and three observed no influence.

In addition to the examination of success, another important leverage point for unleashing the potential of crowdfunding for sustainable development is researching the post-funding phase of crowdfunding (Hörisch 2019) — that is, investigating the extent to which the financial resources acquired by sustainable entrepreneurship via crowdfunding are used to create actual contributions to sustainable development once the funding is completed. However, only two of the 83 papers in the sample dealt with the post-funding phase. The absolute numbers of papers examining the respective crowdfunding phases are summarized in Table 5.

\section{Discussion and conclusions for future research}

The results of this systematic literature review demonstrate that the research field at the interface of crowdfunding and sustainability has not yet been extensively studied. The number of papers published per year indicates that the field is still in development but that it is growing. Additionally, the lack of theories originating from the field of crowdfunding and sustainability and the rather small percentage of papers applying theories at all suggest that the research field is in a nascent stage, if assessed against the criteria suggested by Edmondson and McManus (2007). According to the concept of methodological fit, in this state of research and theory in particular, qualitative methods, open-ended inquiries, the identification of

Table 5 Number of articles researching different crowdfunding phases

\begin{tabular}{lcl}
\hline Crowdfunding phase & Number of articles & $\begin{array}{l}\text { Percentage } \\
\text { of articles } \\
(\%)\end{array}$ \\
\hline Pre-funding phase & 39 & 47 \\
Post-funding phase & 2 & 2 \\
No focus on any phase & 42 & 51 \\
\hline
\end{tabular}


patterns, thematic content analysis, and suggestive theories are useful to expand the insight in the field (Edmondson and McManus 2007).

Still, the shift toward applying quantitative methods signals a development of the field in a more mature direction, even though the history of the research field is remarkably short. Comparing the latter with the similarly short history of the broader research field of crowdfunding in general, it becomes apparent that the connection of crowdfunding and sustainability has been considered since the beginning of the study of crowdfunding. Remarkably, the oldest publication on crowdfunding and sustainability included in this systematic literature review was published in 2011 - the same year in which the first paper on crowdfunding in general was published, as identified in Jovanovic's (2018) systematic literature review. Likewise, the scant use of theories was found in Jovanovic's (2018) review, as was the recent shift toward quantitative methods. In accordance with the latter, Bouncken et al. (2015) also reported a lack of quantitative crowdfunding studies until the year 2014 .

Furthermore, the above analysis identifies clear foci in the current research on crowdfunding and sustainability; in other words, certain aspects of crowdfunding or sustainability experience particularly high levels of academic attention. If these foci are contrasted with the relevance of these aspects in practice or to earlier research in the broader fields of crowdfunding or sustainability science, some substantial deviations become visible. First, with regard to the dimensions of sustainability considered in crowdfunding research, there is a substantial dominance of social aspects. In the systematic literature review by Jovanovic (2018), the environmental dimension was not even mentioned among the various foci identified. This dominance of social aspects seems to be inconsistent with the general research on sustainability and its definitions, which emphasizes the equal importance and balance of the social and environmental dimensions. In an analysis of frequently used terms in definitions of sustainability, White (2013) found that references to the terms environment and social are not only the most common but also occur at nearly equal frequencies, with environmental aspects being mentioned even slightly more frequently than social aspects. This suggests that the dominance of the social dimension is by no means embodied in the definition of sustainability but is specific to the research field focusing on crowdfunding and sustainability. Future research at this intersection could therefore more strongly focus on aspects of environmental sustainability, such as relating to the concept of planetary boundaries and complementarily testing whether this dominance of the social dimension in research is also prevalent in practice. In addition, while current descriptions of the concept of sustainability highlight the interconnectedness of the different dimensions embodied in the concept (e.g., Bañon Gomis et al. 2011; Adams 2006), only 13\% of the papers in the sample of the current review integrated the social and environmental dimensions of sustainability. This demonstrates a need for future research that accounts for the interconnected nature of the dimensions of sustainability.

Regarding the various types of crowdfunding, the dominance of lending-based crowdfunding in practice is not reflected in current research at the intersection between sustainability and crowdfunding (only 13 articles in the current review focused on lending-based crowdfunding). In contrast, donation-based crowdfunding received the highest level of attention in the research. Consequently, future research 
is challenged with overcoming this imbalance by conducting more research on lending-based crowdfunding. Interestingly, in her review of crowdfunding research in general, Jovanovic (2018) observed a dominance of research on reward-based crowdfunding and found lending-based crowdfunding to be the least-researched type of crowdfunding (only five articles focused on lending-based crowdfunding). This suggests that while the lack of research on lending-based crowdfunding is not specific to the research field at the intersection of crowdfunding and sustainability, the dominance of research on donation-based crowdfunding is specific to this field.

Concerning the different functions of crowdfunding, the scarcity of research on the marketing function and the absence of research on the legitimizing function of crowdfunding is surprising. Particularly, the latter research gap offers interesting avenues for future inquiries, as sustainable entrepreneurship bears great potential for securing legitimacy (e.g., Cho 2009; Milanes-Montero and Perez-Calderon 2011; Schaltegger and Hörisch 2017) and it remains open for investigation as to whether crowdfunding could help to unleash this potential.

A sharp contrast between the current state of research on crowdfunding and sustainability and research on crowdfunding in general can also be observed in terms of the phases of crowdfunding analyzed (i.e., the pre- and post-funding phases). In terms of crowdfunding in general, research that explores the ethical questions of fraudulent and failing crowdfunding projects in the post-funding phase has experienced substantial attention (e.g., Hossain and Oparaocha 2017; Snyder et al. 2016); however, this post-funding phase remains scarcely investigated in the context of sustainability-oriented crowdfunding projects. Analyzing the post-funding phase in this context will be crucial to more realistically assess the practical contribution of crowdfunding to sustainable development. In this respect, contrasting the actual contributions of successfully financed crowdfunding projects with relevant reference points such as the United Nations Sustainable Development Goals (UN 2015) or planetary boundaries (Rockström et al. 2009; Steffen et al. 2015) seem particularly promising approaches. Without the assessment of the sustainability impact of sustainable crowdfunding campaigns, the extent of the contribution of crowdfunding for sustainable development can hardly be estimated. Investigating the post-funding phase may also indicate the extent to which sustainability-oriented crowdfunding projects sensitize society to environmental and social issues (cf. Messeni Petruzzelli et al. 2019).

Furthermore, future studies are advised to more deeply analyze and compare the suitability of specific crowdfunding types and platforms for financing environmental- and social-oriented crowdfunding projects. This could be implemented by comparing different crowdfunding types or thematic platforms (i.e., conventional versus sustainability-oriented platforms) within one dataset. In recent years, studies focusing on crowdfunding platforms in general emerged (e.g., Rossi and Vismara 2018; Rossi et al. 2019), and among the papers analyzed for this review, three investigated different aspects of crowdfunding platforms. Still, it has not yet been researched whether sustainability-oriented platforms (e.g. ecocrowd, bettervest) show higher success rates for sustainability-oriented campaigns than do thematically open platforms (e.g. kickstarter, seedmatch, indiegogo or startnext). Last, for the purpose of enhancing the potential of crowdfunding for sustainable development, 
future research on sustainability and crowdfunding should pay more attention to less frequently analyzed research objects, such the initiators of sustainability-oriented crowdfunding projects (on which only seven articles in the current review focused).

In earlier analyses, inconsistent findings were reported with regard to the research foci of the general crowdfunding literature. For example, Jovanovic (2018) identified only two studies within the studied database that conducted research on project initiators. In contrast, Messeni Petruzzelli et al. (2019) found that several studies had already addressed the characteristics of project initiators and their influence on the success of a crowdfunding campaign. Based on the results of this literature review, more research is recommended with regard to the initiators of environmental- or social-oriented crowdfunding campaigns. Furthermore, the existing and potential target groups of sustainability-oriented crowdfunding projects remain to be identified; doing so could help facilitate the search for new supporters of sustainabilityoriented crowdfunding projects. In this respect, future investigations should choose supporters of crowdfunding campaigns as their research object, as they have not attracted vast attention by past literature so far.

In addition to the relatively specific paths for future research identified above, to support the development of the field toward higher levels of maturity, more theorizing will be needed. Interestingly, no theory of crowdfunding has evolved even in the general field of crowdfunding research. However, such theory could help to explain the partly contrasting results in the current literature on crowdfunding and sustainability - for example, concerning the influence of a sustainability orientation on crowdfunding success.

Overall, we conclude that the impact of crowdfunding on sustainable development has not yet been thoroughly researched. This systematic literature review has revealed that to comprehensively assess the contribution of crowdfunding to sustainable development, the identified research gaps need to be addressed systematically. Based on earlier work (e.g., Testa et al. 2019; Wehnert et al. 2019; Vasileiadou et al. 2016), we can confirm that crowdfunding holds great potential to contribute to sustainable development. However, there is still a gap in the literature in terms of assesses how this potential can be realized.

In conclusion, this systematic literature review has shown that research on crowdfunding and sustainability is still in its early phase. Several research gaps were identified, and corresponding proposals for future research were formulated. The impact of crowdfunding on sustainable development has not yet been sufficiently researched, despite the great potential of the research area that has been identified in the literature (e.g., Testa et al. 2019; Wehnert et al. 2019; Vasileiadou et al. 2016).

Acknowledgements Open Access funding provided by Projekt DEAL. We would like to thank Carina Lemke and Merle Käberich for supporting the preparation of the analysis.

Funding Funding was provided by Deutsche Bundesstiftung Umwelt (Grant no. 34844/01).

Open Access This article is licensed under a Creative Commons Attribution 4.0 International License, which permits use, sharing, adaptation, distribution and reproduction in any medium or format, as long as you give appropriate credit to the original author(s) and the source, provide a link to the Creative Commons licence, and indicate if changes were made. The images or other third party material in this article are included in the article's Creative Commons licence, unless indicated otherwise in a credit line to the 
material. If material is not included in the article's Creative Commons licence and your intended use is not permitted by statutory regulation or exceeds the permitted use, you will need to obtain permission directly from the copyright holder. To view a copy of this licence, visit http://creativecommons.org/licen ses/by/4.0/.

\section{References}

Adams WM (2006) The future of sustainability: re-thinking environment and development in the twentyfirst century. IUCN The World Conservation Union, Gland

Akerboom S, Botzen W, Buijze A, Michels A, van Rijswick M (2020) Meeting goals of sustainability policy: $\mathrm{CO} 2$ emission reduction, cost-effectiveness and societal acceptance. An analysis of the proposal to phase-out coal in the Netherlands. Energy Policy 138:111210

Alegre I, Moleskis M (2019) Beyond financial motivations in crowdfunding: a systematic literature review of donations and rewards. Voluntas. https://doi.org/10.1007/s11266-019-00173-w

Bañon Gomis AJ, Guillén Parra M, Hoffman WM, McNulty RE (2011) Rethinking the concept of sustainability. Bus Soc Rev 116:171-191

Bapna S (2019) Complementarity of signals in early-stage equity investment decisions: evidence from a randomized field experiment. Manage Sci 65(2):933-952

Barosh L, Friel S, Engelhardt K, Chan L (2014) The cost of a healthy and sustainable diet-who can afford it? Aust Nz J Publ Heal 38(1):7-12

Belleflamme P, Lambert T, Schwienbacher A (2014) Crowdfunding: tapping the right crowd. J Bus Venturing 29:585-609

Bouchard TJ (1976) Field research methods: Interviewing, questionnaires, participant observation, systematic observation, unobtrusive measures. Handbook Ind Organ Psychol 1:363

Bouncken RB, Komorek M, Kraus S (2015) Crowdfunding: the current state of research. Int Business Econ Res J 14:407

Bruton G, Khavul S, Siegel D, Wright M (2015) New financial alternatives in seeding entrepreneurship: microfinance, crowdfunding, and peer-to-peer innovations. Entrep Theory Pract 39(1):9-26

Buchheim L, Krieger A, Arndt S (2019) Innovation types in public sector organizations: a systematic review of the literature. Manag Rev Q. https://doi.org/10.1007/s11301-019-00174-5

Burtch G, Ghose A, Wattal S (2014) Cultural differences and geography as determinants of online prosocial lending. MIS Q Manag Inf Syst 38(3):773-794

Calic G, Mosakowski E (2016) Kicking off social entrepreneurship: how a sustainability orientation influences crowdfunding success. J Manage Stud 53:738-767

Casado GG, de Molina GM (2009) Preindustrial agriculture versus organic agriculture. Land Use Policy 26(2):502-510

Cho CH (2009) Legitimation strategies used in response to environmental disaster: a French case study of total SA's Erika and AZF incidents. Eur Account Rev 18:33-62

Colombo MG, Franzoni C, Rossi-Lamastra C (2015) Internal social capital and the attraction of early contributions in crowdfunding. Entrep Theory Pract 39(1):75-100

Cumming D, Meoli M, Vismara S (2019) Investors' choices between cash and voting rights: evidence from dual-class equity crowdfunding. Res Policy 48(8):103740

De Luca VV, Margherita A, Passiante G (2019) Crowdfunding: a systemic framework of benefits. Int J Entrepreneurial Behav Res 25:1321-1339

Dempsey J (2015) Fixing biodiversity loss. Environ Plann A 47:2555-2572

Edmondson AC, McManus SE (2007) Methodological fit in management field research. Acad Manag Rev 32:1246-1264

Elkuch A, Brunner C, Marxt C (2013) Reciprocal crowdfunding as means to enable student and graduate entrepreneurship in Africa-a case study of Rwanda. Int J Entrepreneurship Small Business 19(4):498-516

Fisch C, Block J (2018) Six tips for your (systematic) literature review in business and management research. Manag Rev Quart 68(2):103-106

Gast J, Gundolf K, Cesinger B (2017) Doing business in a green way: a systematic review of the ecological sustainability entrepreneurship literature and future research directions. J Clean Prod 147:44-56 
Hansen EG, Schaltegger S (2016) The sustainability balanced scorecard: a systematic review of architectures. J Bus Ethics 133:193-221

Harzing AW (2019) Journal Quality List. Sixty-fifth Edition. http://www.harzing.com. Accessed 01 Nov 2019

Heidingsfelder J, Beckmann M (2019) A governance puzzle to be solved? A systematic literature review of fragmented sustainability governance. Manag Rev Q. https://doi.org/10.1007/s11301-019-00170 $-9$

Hoegen A, Steininger DM, Veit D (2018) How do investors decide? An interdisciplinary review of decision-making in crowdfunding. Electron Mark 28(3):339-365

Hörisch J (2015) Crowdfunding for environmental ventures: an empirical analysis of the influence of environmental orientation on the success of crowdfunding initiatives. J Clean Prod 107:636-645

Hörisch J (2018) 'Think big'or'small is beautiful'? An empirical analysis of characteristics and determinants of success of sustainable crowdfunding projects. Int J Entrepreneurial Venturing 10:111-129

Hörisch J (2019) Take the money and run? Implementation and disclosure of environmentally-oriented crowdfunding projects. J Clean Prod 223:127-135

Hossain M, Oparaocha GO (2017) Crowdfunding: motives, definitions, typology and ethical challenges. Entrep Res J. https://doi.org/10.1515/erj-2015-0045

Johnson M, Schaltegger S (2019) Entrepreneurship for sustainable development: a review and multilevel causal mechanism framework. Entrep Theory Pract. https://doi.org/10.1177/1042258719885368

Jovanović T (2018) Crowdfunding: what do we know so far? Int J Innov Technol Manag 16:1950009

Kardos M (2012) The relationship between entrepreneurship, innovation and sustainable development. Research on European Union countries. Procedia Econom Finance 3:1030-1035

Kraus S, Filser M, Odwyer M, Shaw E (2014) Social entrepreneurship: an exploratory citation analysis. Rev Manag Sci 8:275-292

Lam PT, Law AO (2016) Crowdfunding for renewable and sustainable energy projects: an exploratory case study approach. Renew Sustain Energy Rev 60:11-20

Lambert T, Schwienbacher A (2010) An empirical analysis of crowdfunding. Social Sci Res Netw 1578175:1-23

Lehner OM (2013) Crowdfunding social ventures: a model and research agenda. Venture Cap 15:289-311

Lehner OM, Kansikas J (2013) Pre-paradigmatic status of social entrepreneurship research: a systematic literature review. J Social Entrepreneurship 4:198-219

Lehner OM, Nicholls A (2014) Social finance and crowdfunding for social enterprises: a public-private case study providing legitimacy and leverage. Ventur Cap 16(3):271-286

Martin T (2012) The JOBS act of 2012: Balancing fundamental securities law principles with the demands of the crowd. SSRN. https://ssrn.com/abstract=2040953. Accessed 6 Nov 2019

Massolution (2015) 2015CF. The crowdfunding industry report. https://reports.crowdsourcing.org/ index.php?route=product/product\&product_id=54. Accessed 1 Aug 2018

Messeni Petruzzelli AM, Natalicchio A, Panniello U, Roma P (2019) Understanding the crowdfunding phenomenon and its implications for sustainability. Technol Forecast Soc 141:138-148

Meyskens M, Bird L (2015) Crowdfunding and value creation. Entrep Res J 5(2):155-166

Milanés-Montero P, Pérez-Calderón E (2011) Corporate environmental disclosure and legitimacy theory: an Europe perspective. Environ Engin Manag J 10:1883-1891

Mochkabadi K, Volkmann CK (2018) Equity crowdfunding: a systematic review of the literature. Small Bus Econ 18(S1):223

Mollick E (2014) The dynamics of crowdfunding: an exploratory study. J Bus Venturing 29:1-16

Pawłowski A (2008) How many dimensions does sustainable development have? Sustain Dev 16(2):81-90

Ridley-Duff R (2009) Co-operative social enterprises: company rules, access to finance and management practice. Social Enterprise J 5:50-68

Rockström J, Steffen W, Noone K et al (2009) A safe operating space for humanity. Natute 461:472-475

Rossi A, Vismara S (2018) What do crowdfunding platforms do? A comparison between investmentbased platforms in Europe. Eurasian Bus Rev 8:93-118

Rossi A, Vismara S, Meoli M (2019) Voting rights delivery in investment-based crowdfunding: a cross-platform analysis. J Ind Business Econom 46(2):251-281

Schaltegger S, Hörisch J (2017) In search of the dominant rationale in sustainability management: legitimacy-or profit-seeking? J Bus Ethics 145:259-276 
Shepherd DA, Patzelt H (2011) The new field of sustainable entrepreneurship: studying entrepreneurial action linking "What Is to Be Sustained" with "What Is to Be Developed". Entrep Theory Pract 35(1): 137-163

Signori A, Vismara S (2018) Does success bring success? The post-offering lives of equity-crowdfunded firms. J Corp Finance 50:575-591

Snyder J, Mathers A, Crooks VA (2016) Fund my treatment! A call for ethics-focused social science research into the use of crowdfunding for medical care. Soc Sci Med 169:27-30

Steffen W, Richardson K, Rockström J et al (2015) Planetary boundaries: guiding human development on a changing planet. Science 347:1259855

Tan KC (2014) Why global justice matters. J Glob Ethics 10:128-134

Testa S, Nielsen KR, Bogers M, Cincotti S (2019) The role of crowdfunding in moving towards a sustainable society. Technol Forecast Soc 141:66-73

Thompson N, Kiefer K, York JG (2011) Distinctions not dichotomies: exploring social, sustainable, and environmental entrepreneurship. In: Lumpkin JT, Katz JA (eds) Advances in entrepreneurship, firm emergence and growth. Social and sustainable entrepreneurship, vol 13, 1st edn. Bingley, Emerald, pp 201-229

Tranfield D, Denyer D, Smart P (2003) Towards a methodology for developing evidence-informed management knowledge by means of systematic review. Br J Manage 14:207-222

Tseng SC, Hung SW (2014) A strategic decision-making model considering the social costs of carbon dioxide emissions for sustainable supply chain management. J Environ Manage 133:315-322

United Nations (2015) Transforming our world: the 2030 Agenda for Sustainable Development. Resolution adopted by the General Assembly on 25 September 2015, New York

Vasileiadou E, Huijben JCCM, Raven RPJM (2016) Three is a crowd? Exploring the potential of crowdfunding for renewable energy in the Netherlands. J Clean Prod 128:142-155

Vismara S (2019) Sustainability in equity crowdfunding. Technol Forecast Soc 141:98-106

Wehnert P, Baccarella CV, Beckmann M (2019) In crowdfunding we trust? Investigating crowdfunding success as a signal for enhancing trust in sustainable product features. Technol Forecast Soc 141:128-137

White R (2013) Environmental harm: an eco-justice perspective. Policy Press, Bristol

Zeng J (2018) Fostering path of ecological sustainable entrepreneurship within big data network system. Int Entrepreneurship Manag J 14(1):79-95

Publisher's Note Springer Nature remains neutral with regard to jurisdictional claims in published maps and institutional affiliations. 